\title{
Ex Fide Lux - Aus dem Glauben kommt das Licht
}

Deutsch-Rumänisches Institut für Theologie, Wissenschaft, Kultur und Dialog e. V.

\section{AdRIANA FloreA*}

Ex fide Lux heißt eine neue Initiative im Bereich des internationalen theologischen Austauschs. Der Austausch soll zwischen Deutschland und Rumänien stattfinden und setzt somit die Basis für ein Deutsch-Rumänisches Institut für Theologie, Wissenschaft, Kultur und Dialog. Die neugergündete Einrichtung will zukünftig einen Raum für Dialog zwischen den Kirchen Rumäniens, besonders der Rumänischen Orthodoxen Kirche, und den Kirchen in Deutschland und im deutschsprachigen Raum fördern.

Das Institut hat sich folgende Ziele gesetzt: die Förderung des theologischen Austauschs, die Vermittlung und Pflege kirchlicher, akademischer und kultureller Beziehungen zwischen dem deutschsprachigen Raum und Rumänien, die Organisation internationaler Veranstaltungen zu Themen der Theologie, Geschichte, Kultur und Geisteswissenschaften sowie die Förderung des Wirkens der Rumänischen Orthodoxen Metropolie für Deutschland, Zentral- und Nordeuropa (Nürnberg).

Pfarrer Prof. Dr. h. c. Hermann Schoenauer aus Nürnberg ist der Vorsitzende des Vereins und hat zusammen mit anderen Theologen, Wissenschaftlern und Laien, unter ihnen auch der frühere Leiter der Evangelischen Akademie Siebenbürgen/EAS, Pfarrer Prof. h. c. Dr. Jürgen Henkel, ein neues ökumenisches Institut als Brücke zwischen Ost und West gegründet.

\section{Week of Prayer for Christian Unity: "Your right hand, O Lord, glorious in power.” (Exodus 15, 6a)}

At least once a year Christians all over the world are reminded of the prayer Jesus spoke for his disciples "they may be one so that the world may believe" (Jh. 17.21). Christians are encouraged to make visible steps towards a unity in Christ. This year's theme comes from the churches of the Caribbean. They are even today deeply marked by the consequences of colonial exploitation. Very regrettably, during five hundred years of colonialism and enslavement, Christian missionary activity in the region, with the exception

\footnotetext{
* Adriana Florea, Reverend of the Evangelical Church of Augsburg Confession in Romania - Parish of the Black Church in Brasov/ Pfarrerin der Evangelischen Kirche A.B. in Rumänien - Honterusgemeinde Kronstadt; e-mail: florea.adri@gmail.com
} 
of a few outstanding examples, was closely tied to this dehumanizing system and in many ways rationalized it and reinforced it. The Caribbean Christians of today have faith that God is active in helping end the enslavement.

It is a uniting experience of the saving action of God which brings freedom. For this reason the choice of the song of Moses and Miriam (Ex. 15.1-21), as the theme of the Week of Prayer for Christian Unity 2018 was considered most appropriate. ${ }^{1}$

In order to mark this Week of Prayer for Christian Unity, presidents of CEC and the Council of European Bishops' Conferences (CCEE) have jointly issued a message. In their message they emphasize the fact that today's Europe needs hope. The hope Europe needs is not one that politics or other secular doings can give to people. The hope the world needs has its roots in God. Everyone who is open to God's Word will be able to discover the other, the suffering, the elderly, the unemployed, and feel united with. This can generate hope in the society.

"We Christians want to give witness to our hope which is rooted in a life with Christ. We have certainty that in Christ is it possible to live with peace of mind in these present times and to build a better future with eyes open to eternity." 2

The care for every person and for the whole world and perseverance in the ecumenical journey are other two subjects addressed in the common message.

In the message it is also pointed out that given the challenges we are facing today we can nevertheless build a better future. This better future is possible "only if we follow God and our hearts and do justice, as individuals and as communities"

http://www.oikoumene.org/en/resources/documents/commissions/faith-and-order/xiweek-of-prayer-for-christian-unity/2018/2018, viewed on $17^{\text {th }}$ January 2018.

2 https://www.ceceurope.org/week-of-prayer-for-christian-unity-your-right-hand-o-lordglorious-in-power/; viewed on $17^{\text {th }}$ January 2018.

3 https://www.ceceurope.org/week-of-prayer-for-christian-unity-your-right-hand-o-lordglorious-in-power/; viewed on $17^{\text {th }}$ January 2018. 